\title{
Urban forests, ecosystem services and modeling
}

\section{Editorial}

Half the planet's population lives in cities and this number is rapidly increasing. This fact forces a discussion among scientists, politicians, decision makers and experts about the relationships between urban and non-urban environment.

Urban forests and green spaces cannot be excluded from these discussions for two main reasons. Firstly, the urban environment affects the behavior of non-urban surrounding spaces. For example, soil organic carbon and nutrient pools as well as energy and water fluxes are directly and indirectly affected by urban land-use conversions and these changes can be observed and evaluated in adjacent disturbed and undisturbed forests. ${ }^{1}$ Secondly, in a world that is becoming overcrowded, polluted and with an expansion of land covered by impervious surfaces the alterations given by climate change lead to new challenges for the relationship between people and urban ecosystems. ${ }^{2,3}$

Urban forests and, in general, urban green spaces are an important component of the urban ecotone and they provide several and different environmental, economic and social benefits in term of ecosystem services. ${ }^{4-7}$ They help cities not only to adapt to climate changes but also to attenuate storm water runoff, improve air quality, reduce sound emissions from traffic, neutralize urban heat island effects, regulate ambient temperature, offset greenhouse gas emission, reduce nutrient leaching to groundwater, provide food, ecological corridors, habitat and landscape connectivity, increment biodiversity, improve the carbon sequestration, enhance recreational opportunities, and to reduce stress and crime activity. ${ }^{8-24}$

Urban forests also represent complex socio-ecological systems and their robust and successful governance derives from a resilient interaction between environmental, economic and social factors. They are part of the "environmental infrastructures" that play a central role in maximizing the human and society wellbeing; for this reason, a political and economical equilibrium needs to be found to assure a more livable future for the next generations.

In particular, human and engineering actions and decisions on water, energy, nutrient and carbon cycles and fluxes that characterize the urban context can be of very high impact and can play a crucial role in the definition and quantification of ecosystem services provided by urban forests. ${ }^{25-29}$ Cost and benefits of governance strategies have to be carefully addressed in order to find optimal exploitation strategies that assure urban forest conservation, an optimal quality of the provided ecosystem services, their sustainable use and the minimization of resource over-exploitation.

In this context, a multidisciplinary approach is required in order to solve the problem of making modern cities more resilient and livable. Urban forests (and in general urban green spaces) can be important actors provided that some gaps are overcome: the cultural gap between undisturbed and disturbed forests, the scientific gap between data collection and modeling, the academic gap between disciplines and the practical gap between ecosystem services definition and their quantification.
Volume I Issue 2 - 2017

\author{
Roberto Revelli, 1,2 \\ 'Department of Environment, Land and Infrastructure \\ Engineering, Polytechnic University of Turin, Italy \\ ${ }^{2}$ Pratt School of Engineering, DUKE University, USA
}

\author{
Correspondence: Roberto Revelli, Department of \\ Environment, Land and Infrastructure Engineering, Polytechnic \\ University of Turin, Italy, Pratt School of Engineering, DUKE \\ University, USA, \\ Email roberto.revelli@polito.it, roberto.revelli@duke.edu
}

Received: October 29, 2017 | Published: November 06, 2017

In a recent review ${ }^{29}$ authors claim that "Each of the 21 ecosystem services analyzed had on average 24 different measures, which may indicate the complex reality of ecosystem services and/or suggest a potential lack of consensus on what constitutes an ecosystem service". Now it is time to face with this "complexity" and/or increase the "consensus" in the best possible way.

\section{Acknowledgements}

The ideas expressed in this note have been developed under the H2020 Marie Sklodowska-Curie grants agreement" ECO.G.U.S.Ecosystem services for resilient and sustainable cities: an ecohydrological approach for Green Urban Spaces” (\#701914).

\section{Conflict of interest}

Author declares that there is no conflict of interest.

\section{References}

1. Pouyat R, Groffman P, Yesilonis I, et al. Soil carbon pools and fluxes in urban ecosystems. Environmental pollution. 2002;116(Supplement 1):S107-S118.

2. Grimm NB, Foster D, Groffman P, et al. The changing landscape: ecosystem responses to urbanization and pollution across climatic and societal gradients. Frontiers in Ecology and the Environment. 2008;6(5):264-272.

3. DE Pataki, CG Boone, TS Hogue, et al. Socio-ecohydrology and the urban water challenge. Ecohydrology. 2011;4(2):341-347.

4. Rosenberg DE, Kopp K, Kratsch HA, et al. Value Landscape Engineering: Identifying Costs, Water Use, Labor, and Impacts to Support Landscape Choice1. JAWRA Journal of the American Water Resources Association. 2011;47(3):635-649.

5. Robert FY. Mainstreaming urban ecosystem services: A national survey of municipal foresters. Urban Ecosystems. 2013;16(4):703-722.

6. Salmond JA, Tadaki M, Vardoulakis S, et al. Health and climate related ecosystem services provided by street trees in the urban environment. Environmental Health: A Global Access Science Source. 2016;15(Suppl $1): 36$.

7. Cynnamon D, Martinez Harms MJ, Kendal D. Ecosystem services. In: Ferrini F, van den Bosch CCK, editors. Routledge Handbook of Urban Forestry. London \& UK: Taylor \& Francis; 2017. 
8. Kuo FE, WC Sullivan. Environment and crime in the inner city does vegetation reduce crime? Environment and Behavior. 2001;33(3):343-367.

9. Maas J, Spreeuwenberg P, Westra MVW, et al. Is green space in the living environment associated with people's feelings of social safety? Environment and Planning A. 2009;41(7):1763-1777.

10. Mullaney J, Lucke T, Trueman SJ. A review of benefits and challenges in growing street trees in paved urban environments. Landscape and Urban Planning. 2015;134:157-166.

11. Alessio R, Escobedo FJ, Zerbe S. Quantifying the local-scale ecosystem services provided by urban treed streetscapes in Bolzano, Italy. AIMS Environmental Science. 2016;3(1):58-76

12. Janhall S. Review on urban vegetation and particle air pollution-Deposition and dispersion. Atmospheric Environment. 2015;105:130-137.

13. Vos PE, Maiheu B, Vankerkom J, et al. Improving local air quality in cities: To tree or not to tree? Environmental Pollution . 2013;183:113-122.

14. Klemm W, Heusinkveld BG, Lenzholzer S, et al. Street greenery and its physical and psychological impact on thermal comfort. Landscape and Urban Planning. 2015;138:87-98.

15. Nidzgorski DA, Hobbie SE. Urban trees reduce nutrient leaching to groundwater. Ecological Applications. 2016;26(5):1566-1580.

16. Sheryn DP, Daniels CB, Ely ME. Green infrastructure as life support: urban nature and climate change. Transactions of the Royal Society of South Australia. 2015;139(1):97-112.

17. Shackleton C. Do Indigenous Street Trees Promote More Biodiversity than Alien Ones? Evidence Using Mistletoes and Birds in South Africa. Forests. 2016;7(7).

18. Matthews T, Lo AY, Byrne JA. Reconceptualizing green infrastructure for climate change adaptation: barriers to adoption and drivers for uptake by spatial planners. Landscape and Urban Planning. 2015;138:155-163.
19. Byrne J, Jinjun Y. Can urban greenspace combat climate change? Towards a subtropical cities research agenda. Australian Planner. 2009;46(4):36-43.

20. Byrne JA, Lo AY, Jianjun Y. Residents' understanding of the role of green infrastructure for climate changes adaptation in Hangzhou, China Landscape and Urban Planning. 2015;138:132-143.

21. Brown RD, Vanos J, Kenny N, et al. Designing urban parks that ameliorate the effects of climate change. Landscape and Urban Planning. 2015;138:118-131.

22. Nowak DJ, Crane DE. Carbon storage and sequestration by urban trees in the USA. Environmental Pollution. 2002;116:381-389.

23. Thompson CW, Roe J, Aspinall P, et al. More green space is linked to less stress in deprived communities: Evidence from salivary cortisol patterns. Landscape and Urban Planning. 2012;105(3):221-229.

24. Mace G, Masundire H, Baillie J, et al. Biodiversity. In Ecosystems and human well-being: current state and trends: findings of the condition and trends working group. In: Hassan R, Scholes R, editors. Washington DC, USA: Island Press; 2005. p. 1-46.

25. Kaye JP, Groffman PM, Grimm NB, et al. A distinct urban biogeochemistry? Trends in Ecology \& Evolution. 2006;21(4):192-199.

26. Bolund P, Hunhammar S. Ecosystem services in urban areas. Ecological Economics. 1999;29:293-301.

27. Pataki DE, Carreiro MM, Cherrier J, et al. Coupling biogeochemical cycles in urban environments: ecosystem services, green solutions, and misconceptions. Frontiers in Ecology and the Environment 2011;9(1):27-36

28. Gomez-Baggethun E, Barton DN. Classifying and valuing ecosystem services for urban planning. Ecological Economics. 2013;86:235-245.

29. Boerema A, Rebelo AJ, Bodi MB, et al. Are ecosystem services adequately quantified? Journal of Applied Ecology. 2017;54(2):358-370. 